\title{
Double-C hold for bag-mask ventilation during resuscitation
}

\author{
Markus Isser $^{1} \cdot$ Hannah Salchner ${ }^{2} \cdot$ Wolfgang Lederer $^{2} \mathbb{D}$
}

Received: 26 March 2021 / Accepted: 12 April 2021 / Published online: 24 April 2021

(c) The Author(s) 2021

Keywords Airway control $\cdot$ Basic cardiac life support $\cdot$ Resuscitation

To the Editor:

"Aerosol extractor for airway management of COVID-19 patients" by Tomoyuki Saito, Asuka Fujishiro and Takashi Asai deals with an important topic [1]. Continuous orotracheal suctioning can minimize exhaled air dispersion during coughing bouts [2]. We liked to highlight two additional protective measures, in particular, the double-C hold in bag-mask ventilation [3] and blanketing the patient with a thin plastic barrier [4]. A good seal for bag-mask ventilation increases efficacy and reduces the risk of contamination with aerosols.

Blanketing the patient with a thin plastic barrier can diminish the risk of contamination from aerosols, vomitus, blood, and body secretions [4]. The foil conforms to the face with a central perforation to ensure air-tight installation of the mask below the shield with filter, valve and bag above. Aerosols from air leakage are removed by adhesion and drainage below the barrier.

\section{Declarations}

Conflict of interest The authors declared that they have no conflicts of interest.

This comment refers to the article available online at https://doi. org/10.1007/s00540-021-02916-w.

Wolfgang Lederer

wolfgang.lederer@i-med.ac.at

1 Medical Division, Mountain Rescue Tyrol, Florianistr. 2, 6410 Telfs, Austria

2 Department of Anesthesiology and Critical Care Medicine, Medical University of Innsbruck, Anichstr. 35, 6020 Innsbruck, Austria
Open Access This article is licensed under a Creative Commons Attribution 4.0 International License, which permits use, sharing, adaptation, distribution and reproduction in any medium or format, as long as you give appropriate credit to the original author(s) and the source, provide a link to the Creative Commons licence, and indicate if changes were made. The images or other third party material in this article are included in the article's Creative Commons licence, unless indicated otherwise in a credit line to the material. If material is not included in the article's Creative Commons licence and your intended use is not permitted by statutory regulation or exceeds the permitted use, you will need to obtain permission directly from the copyright holder. To view a copy of this licence, visit http://creativecommons.org/licenses/by/4.0/.

\section{References}

1. Saito T, Fujishiro A, Asai T. Aerosol extractor for airway management of COVID-19 patients. J Anesth. 2021;35:323. https://doi. org/10.1007/s00540-021-02916-w.

2. Chan MTV, Chow BK, Lo T, Ko FW, Ng SS, Gin T, Hui DS. Exhaled air dispersion during bag-mask ventilation and sputum suctioning-implications for infection control. Sci Rep. 2018;8(1):198. https://doi.org/10.1038/s41598-017-18614-1.

3. Nolan JP, Monsieurs KG, Bossaert L, Böttiger BW, Greif R, Lott C, Madar J, Olasveengen TM, Roehr CC, Semeraro F, Soar J, Van de Voorde P, Zideman DA, Perkins GD; European Resuscitation Council COVID-Guideline Writing Groups. European resuscitation council COVID-19 guidelines executive summary. Resuscitation. 2020;153:45-55. https://doi.org/10.1016/j.resuscitation. 2020.06.001.

4. Matava CT, Yu J, Denning S. Clear plastic drapes may be effective at limiting aerosolization and droplet spray during extubation: implications for COVID-19. Can J Anaesth. 2020;67(7):902-4. https://doi.org/10.1007/s12630-020-01649-w.

Publisher's Note Springer Nature remains neutral with regard to jurisdictional claims in published maps and institutional affiliations. 